

\title{
Individual Transferable Quotas in the Baltic Sea Herring Fishery: a Socio- bioeconomic Analysis
}

\author{
Kulmala, S., ${ }^{1}$ Peltomäki, H., ${ }^{2}$ Lindroos, M., ${ }^{1}$ Kuikka, S., ${ }^{2}$ \& Söderkultalahti, P. ${ }^{3}$ \\ ${ }^{1}$ University of Helsinki, Department of Economics and Management, Finland; ${ }^{2}$ University of \\ Helsinki, Department of Biological and Environmental Sciences, Finland; ${ }^{3}$ Finnish Game and \\ Fisheries Institute, Helsinki, Finland
}

\begin{abstract}
Our aim is to study the possible economic, biological and social effects of the individual transferable quotas (ITQs) for the Finnish herring fishery. First, we carry out the bioeconomic analysis of Finnish herring fishery. The model observes two optional management schemes: ITQ-system and IQ-system with non-transferable quotas. Secondly, the qualitative part of the study consists of the interviews of Finnish fishermen. We find that current management of the Finnish herring fishery is far from biologically and economically sound management. The economic advice is biologically more conservative than the current biological advice. According to simulation results ITQ-system is a good alternative for the current total allowable catch (TAC) based management. The results of interviews show that ITQ-system would likely be supported by the fishermen.
\end{abstract}

Key words: Baltic herring, ITQ, bioeconomic modelling, fishermen interviews

\section{Introduction}

Baltic herring (Clupea harengus membras (L.)) is the most important species in the Finnish fishery metered by the landings and the value of landings (FGFRI, 2003a). Currently, the fishery is regulated by the national annual total allowable catch (TAC), fishing time restrictions and entry limitations. However, the Finnish herring fleet is considered too big compared to the TAC, which has been declining with the herring stock. The economic performance of Finnish herring fleet is moderate due to the diminishing number of vessels, but the long-term predictions suggest a declining trend in profitability (Anon, 2003). The use of single TAC has lead to a closure of the fishery in the end of the year, when the demand of herring for Christmas is high. The unfavourable features of single TAC policy, a need for the improvement of economic performance of Finnish herring fishery and the request of fishermen upon a reorganisation of the current fisheries management create a policy relevant basis for present study.

In addition to practical reasons for studying IQ-based regulation system, a large bioeconomic literature establishes the incapability of TAC or entry limit policies for solving the biological or economic overfishing problem (Gordon, 1954; Adasiak, 1979; Fraser, 1979; Clark, 1980). 
Also, the basic idea, advantages and problems of different kinds of individual quota based management systems are well known within fisheries economists (see e.g. Clark, 1980; Hannesson, 1991; Squires et al., 1998). Within the IQ-based management system the TAC is divided into smaller quotas. Fishermen and fishing firms can buy these quotas after which, they are free to choose when and how to fish. If quotas are transferable fishermen can buy, sell or lease quotas in quota markets.

Nowadays individual transferable quotas (ITQs) are widely implemented from which New Zealand, Iceland, Australia, US and Estonia are examples (Arnason, 1990; Campbell et al., 2000; Gridle \& Macinko, 2000; Vetemaa et al., 2002; Batsone \& Sharp, 2003). Albeit the ITQs have not and probably will not solve all the commercial fishery problems, the general consequence of the implementation of ITQ-system is the improvement over current practices, or possible alternative management schemes (Squires et al., 1998). Fisheries scientists worldwide agree that property rights based fishery management including ITQs are the best way to organize the fishing activity (Arnason \& Gissurarson,1999; Grafton, 1996).

The influence of fisheries management on fishing industry's practices and fishermen's working circumstances is significant. However, the managers, instead of working with fishermen, have co-operated with fisheries scientists and economists (Couper \& Smith, 1997). Since the ineffectiveness of science-based management, the administrators have started to pay more attention to the utilization of fisher's knowledge (Maurstad, 2001). According to Jentoft (1989) a prerequisite for successful implementation of new fisheries management system is fishermen's approval. Based on these starting points, we will consider the fishermen opinions in order to give policy relevant guidelines for future Finnish herring fisheries management.

In fisheries management, the reviewing of the effects of fishery policy changes after the implementation is the prevailing practice. Perhaps the immediate need for reorganisation exceeds the benefits of the examination of the consequences in advance. On the other hand, after implementation the available data makes the policy analysis easier. Contrary to current practices, this paper examines the effects of potential fishery policy changes in advance. The present study is a first analysis of ITQs in Finnish fisheries; however Mickwiz and Pruuki (1993) discussed the opportunity of using ITQs in Finnish salmon fishery. 
We contribute to the existing literature by combining quantitative and qualitative methods in order to find out the economic, biological and social effects of the possible re-organisation of the Finnish herring fishery management system. We start with a description of the Finnish herring fishery and a review of the characteristics of ITQs. We continue with presenting the bioeconomic model and analysis of the fishery (Kulmala, 2005). We construct a dynamic simulation model which observes the fishing of herring for two purposes: food and fodder. The model allows the comparisons between current, IQ- and ITQ-based management systems. Moreover, we compare the current biological based fisheries management to an economic sound management advice presented here. After numerical analysis, we study the attitudes of Finnish herring fishermen towards fishery management and ask their opinions about IQbased management system (Peltomäki, 2004). In addition, we find out the fishermen thoughts about the attributes of individual quotas, for instance transferability.

\section{Some aspects of Finnish herring fishery and ITQ-systems}

The current Baltic herring fisheries management system has international and national levels. The International Baltic Sea Fishery Commission (IBSFC), based on the stock assessments and biological advice given by the International Council for the Exploration of the Sea (ICES), has decided the annual TACs. The advice has been purely biological for instance, with the aim of keeping a biological risk on an acceptable level. In Finland, the national fisheries managers with the aim to guarantee the adequacy of TAC for whole year, have settled monthly and weekly fishing time bans. In addition, European Union's Common Fisheries Policy regulates the fishing capacity. However, the Finnish herring fleet is considered too big compared to the TAC, which has been declining with the herring stock. The future prospects of the economic performance are poor (Anon, 2003).

Due to the hydrographical and biological changes in the Baltic Sea since 1990, the Finnish herring fishery is centred on the Bothnian Sea (Stephenson et al., 2001). The last ICES assessment suggests that the Bothnian Sea herring stock biomass has been increasing during latest years (see: www.ices.dk/committe/acfm/comwork/report/asp/advice.asp). In 2004 the Finnish Bothnian Sea herring catch was 50000 tonnes, that was $71 \%$ from the total Finnish herring catch (FGFRI, 2005). In addition, the stature of the Bothnian Sea region to the Finnish fishery has built up, since the increased efficiency of the local trawlers and the concentration of the fish processing and fodder industries in the region (FGFRI, 2001a). 
The Finnish herring fishery involves approximately 90 trawlers specialized in herring. Smaller trawlers (with the length of less than $24 \mathrm{~m}$ ) supply herring primarily for fodder, and bigger trawlers (with the length equal or over $24 \mathrm{~m}$ ) supply herring for food. In addition, the trawlers within these segments differ from each other in terms of number of crew. The food herring trawlers have a crew from three to four, but a crew of two men is enough for fodder trawlers. In general, the fodder trawlers do not suite for fishing herring for food due to the quality demands. Consequently, the fishing costs of food herring are higher than the fishing costs of fodder herring; however the market price of food herring is higher than the price of fodder. The Finnish herring fishery, especially the food herring fishery is very concentrated; that is usually only ten percent of herring trawlers harvest herring for food.

\subsection{Economic efficiency}

The most important economic argument on behalf of ITQs is the improvement of profitability. Since every fisherman has a right to fish their quota they do not have an incentive to race for fish. Consequently, the capital invested earlier, for instance in faster boats, can now be spent on quotas. The necessary condition for the improvement of economic performance of the fishery is the transferability of quotas (Moloney \& Pearse, 1979; Clark, 1980). Quota markets enable the concentration of quotas to the most efficient fishing units while giving the fishing units with low profitability an opportunity to give up fishing in return for the quota revenue. (see e.g. Scott, 1999) However, the concentration of fishing rights has also been regarded as one of the most severe problems of ITQs (McCay, 1995).

\subsection{Initial allocation of quotas}

The initial allocation of individual quotas can be based on, for instance, historical catches, or the capacity or value of vessel. Quotas can be given totally free or against some payment. Within some systems, a share of quotas is given free and the rest is auctioned. A right to buy or participate on initial allocation of quotas can be given to all willing people or only professional fishermen, but the latter is the general practice (see e.g. Arnason, 1993; Vetemaa, 2002). The costs of fisheries management or an ITQ-system can be covered, at least partly, by the auction or other payments. The feeling of fishermen, that the initial allocation of quotas is equitable, is a prerequisite for the pursuit of an ITQ-system (Terry, 1993). However, the 
transferability of quotas enables the fishermen to buy or sell their quotas in markets, and consequently, redresses the possible distortion of administrative initial allocation (Clark, 1990).

\subsection{Capital interest}

From the perspective of fish stock conservation, ITQs or IQs that are based on TAC are an effective way of protecting fish stocks, providing that TAC rests on accurate biological knowledge (Hannesson, 1991). Yet, ITQs have been proposed to give an incentive to protect fish stock, since the value of a quota is dependent on the current and future stock size and the future value of the quota. According to Townsend (1992), in order to create real capital interest, saving of quotas should be allowed, and the interest rate of quotas that is equal to growth rate of stock should be determined (even though this is highly variable due to biological variability, see e.g. Stephenson et al., 2001). Consequently, the time horizon becomes part of the fishermen decisions, that is, saving some of the quotas today gives more catch in the future. However, depending on the functionality of quota markets and the dependence of quota price on fish stock assessment, a growth rate -based interest rate might not be necessary condition for the development of capital interest.

How would the management based on individual quotas make a difference for the current situation of the Finnish herring fishery? Would the economic performance of the herring fishery begin look brighter after the implementation of an ITQ-system? What would happen to the size of the herring stock and the size of catches? How do the fishermen see the potential concentration of quotas or the price of quotas? The rest of the paper aims to answer these questions.

\section{Bioeconomic model}

We develop a dynamic bioeconomic simulation model for the Finnish herring fishery. The population dynamics of the herring stock are given as a discrete time and age-structured model, that is, we follow a herring year class from recruitment to virtual death. For instance, a four year old herring in the year $t$ was three years old in the year before $(t-1)$. Equation 1 presents the age-structured dynamics more formally. 


$$
N_{a, t}=N_{a-1, t-1} e^{-Z_{a-1}}
$$

where $N_{a, t}$ is the number of individuals of age $a$ at time $t$. We have nine age groups from age one to age nine. The last age group consists of all at least nine year old herring. Total agespecific mortality $Z_{a}=\left(g F_{a}+M_{a}\right)$ is the sum of age-specific fishing $\left(F_{a}\right)$ and natural $\left(M_{a}\right)$ mortalities. We follow the ICES (International Council for the Exploration of the Sea) method, that is, we use fishing mortality coefficient $g$ to model the changes in fishing mortalities ${ }^{1}$.

The yearly age-specific yield is given by the equation

$$
Y_{a, t}=\left(\frac{g F_{a,}}{Z_{a}}\right) N_{a, t}\left(1-e^{Z_{a}}\right)
$$

and the yearly total yield in biomass is given by the equation

$$
T Y_{t}=\sum_{a=1}^{9} W A_{a} Y_{a, t}
$$

where $W A_{a}$ is the weight at age.

Spawning stock biomass is given as the sum of mature fish over all age groups

$$
S S B_{t}=\sum_{a=1}^{9} N_{a, t} e^{-g F_{a} f+M_{a} m} M O_{a} W A_{a}
$$

where $N_{a, t} e^{-g F_{a} f+M_{a} m}$ is the age-specific stock size at the spawning time, where $f$ and $m$ are the proportions of fishing and natural mortalities that take place before spawning. The proportion of mature individuals among age group is denoted by $M O_{a}$.

\footnotetext{
${ }^{1}$ For example, if ICES recommends the decreasing of BS herring fishing mortality by $20 \%$ that means $\mathrm{g}=0.8$.
} 
We use the Beverton-Holt stock-recruitment relationship defined by ICES

$$
R_{t}=\left(\frac{a S S B_{t-1}}{(1+b) S S B_{t-1}}\right) 1000
$$

where $R_{t}$ is the number of recruits at time (age group 1 in this case), and $a$ and $b$ are the model parameters.

The general form for the economic part of the model follows the equation

$$
\Pi(x, e)=p T Y(g)-g C e
$$

where $g$ is the fishing mortality coefficient. The profit $\Pi$ of fishery depends on the stock size $x$ and on the fishing effort $e$. The first term in the right hand side of the equation is the fishery return where the price of herring is $p$, and $T Y(g)$ is the total yield determined by equation (3). The second term in the right hand side of equation (6), is the fishing cost $g C e$ that is linearly dependent on the fishing effort.

\section{Finnish herring fishery within current and future management systems}

This section constructs the equations that determine the net present value of the profits of the Finnish herring fishery within current TAC-based management and the optional ITQ-system. We follow Arnason (1990), who proposed that in order to have a management system with minimum information needs, the individual quota should be shares of TAC. According to Arnason (1990), all information that is relevant for fisheries managers, for instance fishing costs, already exists in fishing industry, and the ITQ-markets are a tool to reveal this private information.

We estimate the efficiency differences between trawlers with help of eight "model trawl". Characteristics for herring fishery are the specialization of trawlers to harvest herring for food and for fodder. We assume that bigger trawler harvest herring only for food and the smaller trawlers harvest herring strictly for fodder. We title these segments food and fodder, and use 
indexes co and fo to denote them, respectively. According to this assumption, in 2002 there were 21 food trawlers and 65 fodder trawlers in the Finnish fishing fleet. Further, we divide these segments smaller classes according to 2000-2002 catch statistics. Consequently, in terms of efficiency we have 8 trawler classes: 1-4 are food trawlers where the class 1 represents the most efficient food trawlers and classes 5-8 are fodder trawlers where the class 5 represents the most efficient fodder trawlers.

Equations (7-9) determine the net present value of the profits of the Finnish herring fishery within TAC management. Since the quotas or strictly speaking the catches of each trawler is a share of the TAC, these equations determine the Finnish herring fishery within IQ-system.

The profits of food trawlers are given by the equation

$$
\sum_{t=1}^{31} \sum_{i=1}^{4} \pi_{c o}=\sum_{t=1}^{31} \sum_{i=1}^{4} \frac{p_{c o} h_{i} T Y_{t}-c_{c o} e_{i} g}{(1+r)^{t-1}}
$$

where the price of food herring is $p_{c o}, h_{i}$ is the catch proportion of a food trawl from the total yield (equation 3), the fishing costs of food segment is $c_{c o}, e_{i}$ is the number of fishing days of a food trawler and $g$ is the fishing mortality coefficient. Similarly the profits of fodder trawlers are given by the equation

$$
\sum_{t=1}^{31} \sum_{i=5}^{8} \pi_{f o}=\sum_{t=1}^{31} \sum_{i=5}^{8} \frac{p_{f o} h_{i} T Y_{t}-c_{f o} e_{i} g}{(1+r)^{t-1}}
$$

where the price of fodder is $p_{f o}, h_{i}$ is the catch proportion of a fodder trawl from the total yield (equation 3), the fishing costs of fodder segment is $c_{f o}$ and $e_{i}$ is the fishing effort of a fodder trawl. In equations (7) and (8) $t$ is time, $r$ is a discount rate and index $i$ while being one to four refers to food trawlers; values five to eight refers to fodder trawlers.

The multiplication of equations (7) and (8) by the number of vessels in each class gives us the profits of each class, and summing the class profits in both segments gives us the segment's profits. The net present value of Bothnian Sea herring fishery within current or individual quota based management, is given by the equation 


$$
\Pi^{I Q}=\Pi_{c o}^{I Q}+\Pi_{f o}^{I Q}
$$

where the profit of food segment is $\Pi_{c o}^{I Q}$ and the profit of fodder segment is $\Pi_{f o}^{I Q}$.

In order to model the Finnish herring fishery within an ITQ-system we assume that the trading of quotas is allowed, and at the beginning of fishing season, the most efficient trawlers in both segments will buy all quotas. However, the quota trading is allowed only among segments not between them. Consequently, the trawlers in classes one and five stay in the fishery.

The net present value of the food segment profits is given by the equation

$$
\sum_{t=1}^{31} \Pi_{c o}^{I T Q}=\frac{p_{c o} h_{c o} T Y_{t}-c_{c o} e_{c o} t r_{c o} g}{(1+r)^{t-1}}
$$

where the price of food herring is $p_{c o}, h_{c o}$ is the proportion of food herring in total yield (equation 3), $c_{c o}$ is the fishing costs in food segment, $e_{c o}$ is the fishing effort of the most efficient food vessels and $t r_{c o}$ is the number of food trawlers. Respectively, the net present value of fodder segment profits is given by the equation

$$
\sum_{t=1}^{31} \Pi_{f o}^{I T Q}=\frac{p_{f o} h_{f o} T Y_{t}-c_{f o} e_{f o} t r_{f o} g}{(1+r)^{t-1}}
$$

where the variables are same as in equation (10) but the values are fodder segment-specific. The net present value of Finnish herring fishery within ITQ-system is then given by the sum of equation (10) and (11). 


\section{Data}

We calibrate the population dynamics part of the model with the ICES (2003) estimation of Bothnian Sea herring stock (table 1). The values for the recruitment model's parameters $a$ and $b$ are 0.017478867 and 0.00000538 (ICES 2003).

Table 1. Biological parameters (ICES 2003).

\begin{tabular}{lccccccccc}
\hline & Age 1 & Age 2 & Age 3 & Age 4 & Age 5 & Age 6 & Age 7 & Age 8 & Age 9+ \\
\hline N0 & 5290320 & 2333950 & 2913430 & 1279430 & 1819140 & 691960 & 420630 & 442650 & 740000 \\
WA & 0,008 & 0,014 & 0,021 & 0,025 & 0,03 & 0,034 & 0,039 & 0,043 & 0,055 \\
MO & 0,05 & 0,64 & 0,96 & 0,98 & 1 & 1 & 1 & 1 & 1 \\
F & 0,063 & 0,104 & 0,126 & 0,207 & 0,2 & 0,236 & 0,266 & 0,313 & 0,312 \\
\hline
\end{tabular}

Abbreviations:

$\mathrm{N} 0=$ initial abundance (thousands)

$\mathrm{WA}=$ mean weight $(\mathrm{kg})$

$\mathrm{MO}=$ maturity proportion

$\mathrm{F}=$ average fishing mortality in period 2000-2002

In order to estimate the trawling costs we use the fishing costs of Finnish fleet (Anon, 2003). We take the three years (2000-2002) average of running fishing costs per day; that is for trawlers in food segment $2947 € /$ day, and for trawlers in fodder segment $588 €$ / day. Also, the market price of herring varies between the food and fodder segments. According to 20002002 price statistic the average price per kilogram is $0.30 € / \mathrm{kg}$ for food herring and $0.09 € /$ $\mathrm{kg}$ for fodder herring (FGFRI, 2003; FGFRI, 2001b; FGFRI, 2001c).

Table 2 presents the catch proportions $(h)$ and fishing days of trawlers $(e)$ and the number of trawlers per class based on the catch and effort statistics during 2000-2002 (FGFRI). By assumption, within ITQs, the catch proportions of food $\left(h_{c o}\right)$ herring and fodder $\left(h_{c o}\right)$ are 55 $\%$ and $45 \%$ respectively. In Bothnian Sea there are 18 food boats and 204 fodder boats (Due to the compilation practices of statistics we consider all trawlers that reported catch over ten kilograms in Bothnian Sean in 2000-2002.) 
Table 2. Catch proportions and the number of trawlers

\begin{tabular}{lllll}
\hline $\begin{array}{l}\text { Class } \\
\text { (i) }\end{array}$ & $\begin{array}{l}\text { Catch \% } \\
\text { (h) }\end{array}$ & $\begin{array}{l}\text { Fishing days } \\
\text { (e) }\end{array}$ & Trawlers \\
\hline 1 & 8.6 & 194 & 4 & \\
2 & 2.2 & 75 & 5 & \\
3 & 1.4 & 54 & 5 & Food \\
4 & 0.4 & 14 & 4 & \\
\hdashline 5 & 0.8 & 62 & 51 & \\
6 & 0.03 & 47 & 51 & Fodder \\
7 & 0.007 & 33 & 51 & \\
8 & 0.0006 & 18 & 51 & \\
\hline
\end{tabular}

\section{Results from bioeconomic analysis}

We analysed the bioeconomic model numerically by using MATLAB (www.mathworks.com). We used a 30 years (2003-2033) simulation period. The revenue realised now are valuable than the revenue realised later, since the net revenue from catches this year can be invested and give a rate of return later. To consider this, we reduced the net revenue from future years by a factor that reflects the return in the market that is the discount rate. Consequently, the results are in terms of net present value, and we used $5 \%$ discount rate.

According to ICES (2003) advice the average of age-specific fishing mortalities that we refer in the current state is 0.20 (Table 1). Simulation results (Table 3) show the present unproductiveness of the BS herring fishery; the net present value (NPV) of the fishery profits is approximately $-80 \mathrm{M} €$. The profit maximising level of $\mathrm{F}$ is 0.04 with individual quotas and 0.08 with individual transferable quotas that are $80 \%$ and $60 \%$ smaller than the current state, respectively. The respective NPVs of the fishery are 9 and $44 \mathrm{M} €$. However, greater gains mean fewer fishermen; 4 of 18 food trawlers and 51 of 204 fodder trawlers stays in the herring fishery after the implementation of ITQs (Table 2). Figure 1 presents the evolution of NPV during simulation period. The current fishing mortality level with ITQ-system projects NPV of $17 \mathrm{M} €$, but after 2017 the fishery is unprofitable. 
Table 3. Current and optimal F with ITQs and IQs, and corresponding NPV

\begin{tabular}{lll}
\hline & F & NPV $(\mathrm{M} €)$ \\
\hline Current state & 0.20 & -80 \\
Optimum with ITQs & 0.08 & 44 \\
Optimum with IQs & 0.04 & 9 \\
\hline
\end{tabular}

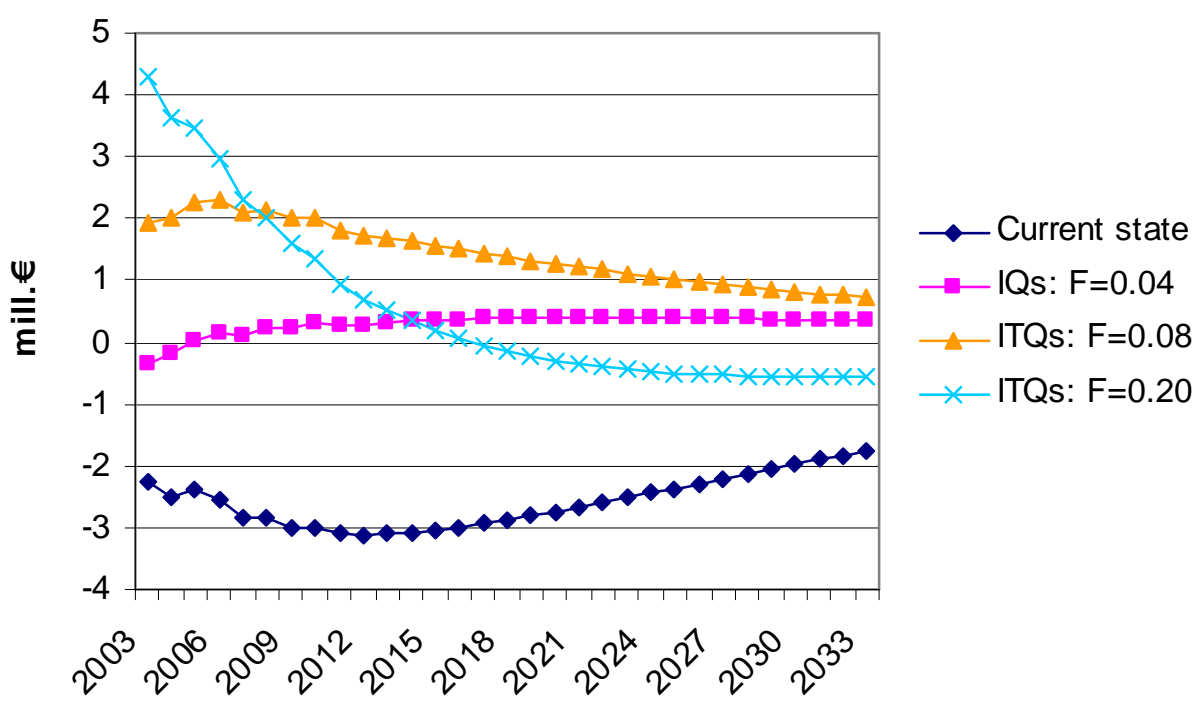

Fig. 1. Net present value of BS herring fishery in 2003-2033 simulated with $5 \%$ discount rate.

Figure 2 presents the herring catches corresponding to current and the profit maximizing levels of F. With a current fishing mortality of 0.20 , the catch decreases from 40000 tonnes to 10000 tonnes during simulation period. The economic optimal catch near 25000 tonnes available within whole simulation period is about half that of the present catches. The latest ICES advice (see: www.ices.dk/committe/acfm/comwork/report/asp/advice.asp) suggests that F could be 0.21 (a biologically safe fishing mortality according to ICES) and corresponding catch would be 88000 tonnes for the year 2006. However, this catch is based on high recruitment estimates in latest years, not on the long term catch simulations by S/R models as in our case. 


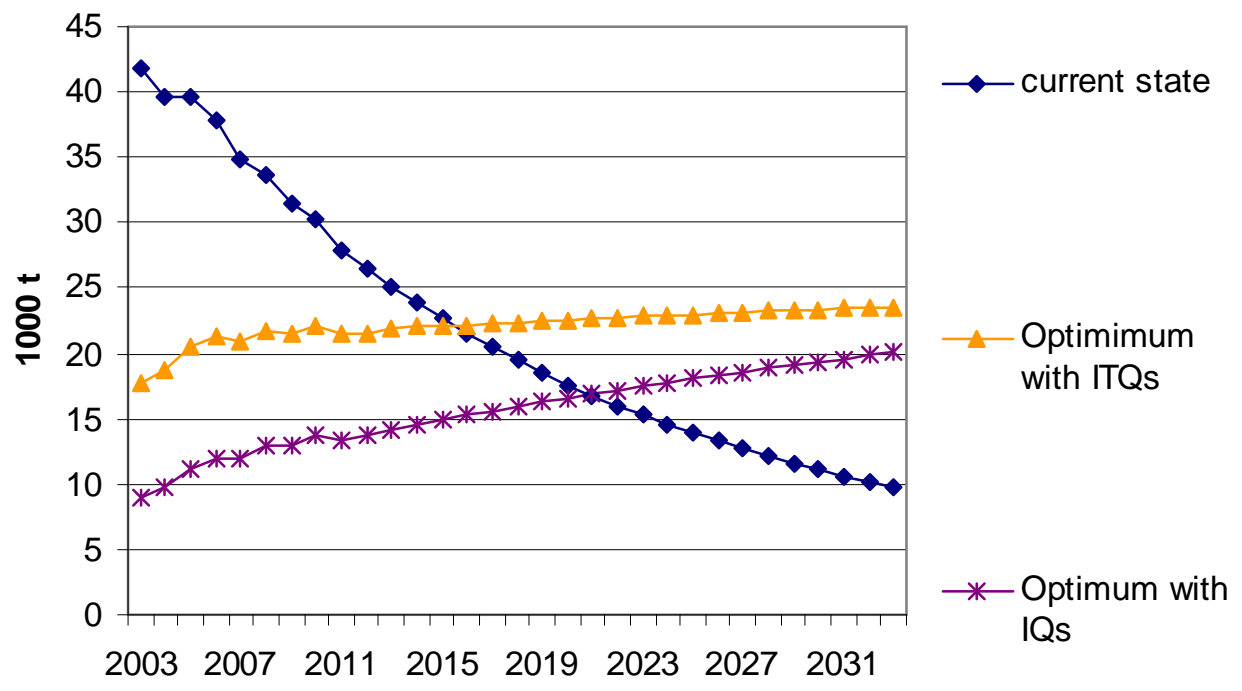

Fig. 2. BS herring catch in 2003-2033 with current and optimal fishing mortalities.

The effects of different management systems and the maximization of profits on the BS herring spawning stock biomass are presented in Figure 3. ICES (2003) proposes that according to precautionary principle, the BS herring spawning stock biomass should not be lower than 200000 tonnes, and the probability of lower recruitment increases if the spawning stock biomass is 145000 tonnes. Obviously, within the ITQ-system, the spawning stock size is higher than the precautionary principle requires.

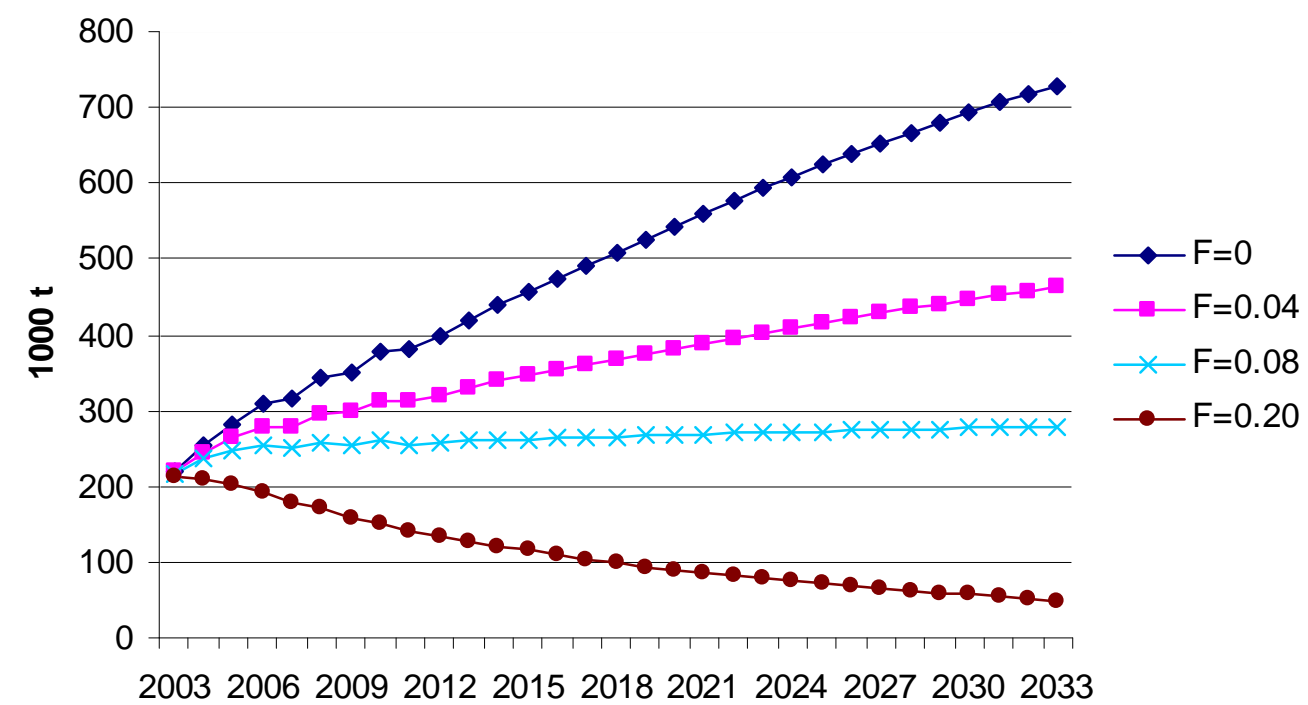

Fig. 3. BS herring spawning stock biomass with different fishing mortalities in 2003-2033. 
The most significant difference between biological and economic advice is that the biological advice does not take into account fishing costs. We carry out the analysis without fishing costs by maximizing the net present value of landings. Table 4 presents the simulation results without fishing costs and with a five percent discount rate. Consequently, the difference between economic optimal fishing mortalities and biological advice is only $10 \%$. However, in economic terms, the result that ignores fishing costs is misleading, proposing an NPV of 72 million euros, since the analysis carried out with fishing costs results a loss of 80 million euros (Table 3). Comparison between the simulation results with and without fishing costs (Tables 3 and 4) clearly demonstrate that the purely biological advice that ignores fishing costs, leads to a lower stock size than economic advice and, especially, to lower incomes to fishermen.

Table 4. Current and optimal F with ITQs and IQs, and corresponding NPV without fishing costs

\begin{tabular}{lll}
\hline & F & NPV (M€) \\
\hline Current state & 0.20 & 72 \\
Optimum with ITQs & 0.18 & 88 \\
Optimum with IQs & 0.18 & 71 \\
\hline
\end{tabular}

Table 5 illustrates the effects of quota price on the NPV and the optimal fishing mortalities. Since the quota price was not actually determined on the quota market, we tested the sensitivity of results to the quota price by assuming the price to be one, three or five percent of the value of yearly landings. Due to the linear dependency between fishing effort and fishing costs, a small increase in fishing costs induces a significant decrease in the NPV. If the food and fodder herring fishery is managed separately, the NPV of the fishery increases from 44 million euros to 47 million euros. In order to maintain the profitability of fodder herring fishery, the fodder quotas should be free. However, the food segments profitability remains good with all tested prices. 
Table 5. The effect of quota price on food and fodder segments and on fishery as a whole

\begin{tabular}{lccccccc}
\hline & \multicolumn{2}{c}{ Food } & \multicolumn{2}{c}{ Fodder } & \multicolumn{2}{c}{$\Sigma$} & \multicolumn{2}{c}{ Whole fishery } \\
\hline $\begin{array}{l}\text { Quota price \% } \\
\text { from catch value }\end{array}$ & NPV & F & NPV & F & NPV & NPV & F \\
$(\mathrm{M} €)$ & & & & $(\mathrm{M} €)$ & $(\mathrm{M} €)$ & \\
\hline 0 & 44 & 0.10 & 3 & 0.04 & 47 & 44 & 0.08 \\
1 & 27 & 0.08 & -0.3 & 0.02 & 27 & 22 & 0.06 \\
3 & 26 & 0.08 & -0.4 & 0.02 & 26 & 21 & 0.06 \\
5 & 25 & 0.06 & -0.6 & 0.02 & 24 & 12 & 0.06 \\
\hline
\end{tabular}

\section{Fishermen interviews}

Using theme interview with open-ended questions and a form with structured questions, we interviewed personally 13 Finnish herring fishermen about their attitudes towards fisheries management in general, and towards individual quota based management. Five of the interviewees were targeting mainly herring for food, and eight of them were specialized on fodder. Initially, we selected 15 Finnish herring fishermen. We chose 5 fishermen that according to catch statistics had the greatest catch in 2002. In addition, we took a random sample of the fishermen that had harvested more than 50 tonnes herring in 2002; from this sample we chose randomly 10 fishermen. In 2002, 59 fishermen harvested herring more than 50 tonnes. We limited our sampling to 50 tonnes, since the focus of the present study were on professional fishermen. Two of the 15 fishermen did not harvest in 2003, therefore we excluded them from the interviews. The interviewed fishermen harvested nearly $24 \%$ of the Finnish herring catch in 2002. Before personal interviews, we sent a request for interview and a short description about ITQs to fishermen. All contacted fishermen agreed to our request.

Table 6 presents background information about the companies of interviewed fishermen. On average, the investments and turnovers of food herring companies are greater than the fodder companies. In addition, the number of employees is higher in the food herring companies than fodder companies. The proportion of fishery income from the total income is $>80 \%$ for 12 of 13 fishermen. 
Table 6. Background information

\begin{tabular}{|c|c|c|c|}
\hline & $\begin{array}{l}\text { Fodder } \\
(\mathrm{n}=8)\end{array}$ & $\begin{array}{l}\text { Food } \\
(\mathrm{n}=5)\end{array}$ & $\begin{array}{c}\text { Total } \\
(\mathrm{n}=13)\end{array}$ \\
\hline \multicolumn{4}{|l|}{ 1. Company form } \\
\hline Self-employed person & 3 & 1 & 4 \\
\hline Company & 1 & 1 & 2 \\
\hline Partnership & 1 & 2 & 3 \\
\hline Limited company & 3 & 1 & 4 \\
\hline \multicolumn{4}{|l|}{ 2. Turnover $(€)$} \\
\hline$<200000$ & 4 & 0 & 4 \\
\hline$\geq 200000$ & 4 & 4 & 8 \\
\hline No answer & 0 & 1 & 1 \\
\hline \multicolumn{4}{|c|}{ 3. Value of investments $(€)$} \\
\hline$<200000$ & 4 & 0 & 4 \\
\hline $200000-1000000$ & 4 & 1 & 5 \\
\hline$>1000000$ & 0 & 3 & 3 \\
\hline No answer & 0 & 1 & 1 \\
\hline \multicolumn{4}{|c|}{ 4. Number of employees } \\
\hline$<3$ & 6 & 0 & 6 \\
\hline $3-6$ & 2 & 2 & 4 \\
\hline$>6$ & 0 & 3 & 3 \\
\hline \multicolumn{4}{|c|}{$\begin{array}{l}\text { 5. Fishery income's proportion }(\%) \text { from total income in } \\
2002\end{array}$} \\
\hline$>80$ & 7 & 5 & 12 \\
\hline $50-80$ & 1 & 0 & 1 \\
\hline \multicolumn{4}{|c|}{$\begin{array}{l}\text { 6. Proportion of herring and sprat from total income in } \\
2002\end{array}$} \\
\hline$>80$ & 6 & 5 & 11 \\
\hline $50-80$ & 1 & 0 & 1 \\
\hline $30-50$ & 1 & 0 & 1 \\
\hline
\end{tabular}

Interview questions covered different aspects of fisheries management and the characteristics of the ITQ-system. Questions from the following categories are examined here: 1) attitudes to fishery management 2) for and against ITQs 3) attributes of quotas 4) initial allocation of quotas 5) saving 6) traditions and future prospects. The objectives of the structured questions were to ensure qualitative analysis as well to gather background information. A summary of the form interview is presented in Table 7.

\subsection{Fisheries management}

Seven of the eight fodder herring fishermen and three of the five food herring fishermen considered that the herring fishery should be regulated in some way. Three fishermen saw the regulations as unnecessary. The majority of interviewees stated that fishery is sufficiently 
regulated by herring demand. The most often mentioned benefit of current management system was "obligatory day offs". Fishermen reported several problems with current management: 1) the amount of different restrictions, 2) the possibility not to choose the fishing days within weeks, 3) a too small national TAC, 4) competition 5) unfriendly relationships between fishermen, 6) fishing costs increasing management scheme, 7) shortterm changes in regulations.

\subsection{For and against individual quota -based management}

The majority of fishermen believed that the IQ-based management increases the profitability of the fishery and decreases the competition between the fishermen. According to them, removal of fishing time restrictions prepares the way for increasing profitability by lengthening and lessening fishing trips and decreasing the labour costs. They also stressed the possibility for long-term business planning opened up by own quotas. Improving the quality of fish or higher herring price was mentioned by half of the respondents.

All five food herring fishermen believed that after the implementation of ITQs, the proportion of food herring in the total catch would increase. Generally, the food herring markets were regarded the major factor regulating the fishing of herring for food. The fodder herring fishermen thought that entry into food herring markets is almost impossible.

Discarding and inadequate quota were the most often mentioned problems and concerns. Five of eight fodder herring fishermen and three of five food herring fishermen believed the on going concentration of fishing. However, in any case many fishermen saw the concentration unavoidable. In addition, few respondents did not find the concentration negative.

\subsection{The attributes of individual quotas}

More than half of the fishermen stated that the quota ownership should be boat-specific. They think that a boat is the harvesting unit. In addition, they regarded the fishermen-specific quotas too complex. The majority of fishermen called for permitting the ownership of quotas only for professional fishermen. 
The quota attribute that polarized the fishermen into supporters and opponents was transferability. The supporters emphasized the increased flexibility and the opportunity for monetary compensation created by transferability. The opponents expressed their serious concern about the quota market speculations and concentration of quotas induced by transferability. Anyhow, to some extent, the majority of fishermen supported transferability (Table 7). The majority of fishermen thought that the price of quota will be very low. They supposed the price to be only few percent of the value of landings due to the cheap price of herring. Two respondents stated not to participate on the potential quota markets.

\subsection{Initial allocation of quotas}

Most fishermen called for free initial allocation of quotas to active boats. Two of 13 fishermen accepted a token quota payment. The minority of fishermen supported the auctions for tiny shares of quotas after the major part of the quotas were allocated for free. The majority of fishermen regarded the duration of ownership as prerequisite for the occurrence of the ITQs benefits. The most important basis for initial allocation that 12 fishermen mentioned, were historical catches. The fishermen of food herring emphasized that the initial allocation of quotas should be based on the value of boat and fishing equipment.

\subsection{Quota savings}

The majority of fishermen expressed their willingness to quota savings or, in principle, preferred quota savings. Only one fisherman believed the savings for biological reasons. In contrast, 8 of 13 fishermen mentioned the possibility for quota savings for economic or other reasons e.g. the low producer price of herring or breakdown might create an incentive for savings. However, the herring growth rate -based interest was considered too theoretical or meaningless. Only three respondents believed that the growth rate -based interest increases savings. Consequently, fishermen did not believe in the development of capital interest.

\subsection{Prospects for future}

The majority of fishermen thought that they would sell their quotas to relatives or friends with cut-prices. However, entering into the fishing industry was not regarded as a vice choice. In 
addition, the fishermen expressed their concerns about the future; heavy restrictions, low profitability, the accumulation of environmental toxins to herring and the uncertain future of fur farming were seen as the major obstacles to develop the fishing industry.

Table 7. The answers of multiple choice questions.

\begin{tabular}{|c|c|c|c|}
\hline & $\begin{array}{l}\text { Fodder } \\
(\mathrm{n}=8)\end{array}$ & $\begin{array}{l}\text { Food } \\
(\mathrm{n}=5)\end{array}$ & $\begin{array}{c}\text { Total } \\
(\mathrm{n}=13)\end{array}$ \\
\hline \multicolumn{4}{|l|}{ 1. Are IQs necessary? } \\
\hline No & 0 & 1 & 1 \\
\hline Yes & 7 & 2 & 9 \\
\hline I do not know / no answer & 1 & 2 & 3 \\
\hline \multicolumn{4}{|l|}{ 2. The ownership of IQs should belong to } \\
\hline fisherman & 2 & 0 & 2 \\
\hline boat & 6 & 3 & 9 \\
\hline fishing firm & 0 & 1 & 1 \\
\hline I do not know / no answer & 0 & 1 & 1 \\
\hline \multicolumn{4}{|l|}{ 3. The quota buying right should be given to } \\
\hline $\begin{array}{l}\text { only for professional fishermen } \\
\text { all interested person }\end{array}$ & $\begin{array}{l}8 \\
0\end{array}$ & $\begin{array}{l}3 \\
1\end{array}$ & $\begin{array}{c}11 \\
1\end{array}$ \\
\hline I do not know / no answer & 0 & 1 & 1 \\
\hline \multicolumn{4}{|l|}{ 4. The best way of initial allocation of quotas is } \\
\hline by free to all active boats & 7 & 2 & 9 \\
\hline to sell quotas to active boats & 0 & 0 & 0 \\
\hline by auctions & 0 & 0 & 0 \\
\hline to give a major part of quotas free and auction the rest & 1 & 3 & 4 \\
\hline to sell major part with fixed price and auction the rest & 0 & 0 & 0 \\
\hline none of previous & 0 & 0 & 0 \\
\hline I do not know / no answer & 0 & 1 & 1 \\
\hline \multicolumn{4}{|l|}{ 5. The best criteria for initial allocation is } \\
\hline historical catches & 7 & 0 & 7 \\
\hline value of boat and equipments & 0 & 0 & 0 \\
\hline combination of previous & 1 & 4 & 5 \\
\hline none of previous & 0 & 0 & 0 \\
\hline I do not know / no answer & 0 & 1 & 1 \\
\hline \multicolumn{4}{|l|}{ 6. Should the quotas be transferable? } \\
\hline without restrictions & 3 & 1 & 4 \\
\hline transitions should be restricted e.g. regionally & 0 & 1 & 1 \\
\hline quotas per owner should be restricted & 2 & 2 & 4 \\
\hline quotas should be non-transferable & 3 & 0 & 3 \\
\hline I do not know / no answer & 0 & 1 & 1 \\
\hline
\end{tabular}

\section{Discussion and conclusion}

We estimated that after the implementation of ITQs, a large increase in the profitability of BS herring fishery - with higher long-term spawning stock - could be possible. The findings support the suggestion of fisheries economists that ITQ-based management system enables 
the improvement of the economic performance of a fishery while sustaining the size of a fish stock. An essential feature of the ITQ-system would be that it offers a voluntary, market based mechanism to decrease the total amount of fishermen costs and capital tied to the herring fishery.

Based on the assumption that after trading within an ITQ-system, the quotas concentrate to the most efficient trawlers; 4 of 18 food trawlers and 51 of 204 fodder trawlers stay in the herring fishery. However, our simulation results suggest that the gains from the implementation of ITQs could be even 124 million euros (from a loss of 80 million euros to a profit of 44 million euros). Probably, the results exaggerate the current losses and the exiting number of trawlers, especially the exiting number of fodder trawlers, since the model calibration considers all trawlers that harvest herring in BS and for many of these trawlers herring is only a bycatch. Consequently, the trawlers that sell their herring quota may continue with fishing for other species. In any event, while the quotas concentrate on the most efficient trawlers, the quitting fishermen will be compensated by selling their quotas. Since fishermen consider the transferability of quota's mainly positive, the interesting question is; how the fishery managers look at the transferability? If the real aim of fishery managers is to maximize the number of fishermen, managers prefer free entry and consequently high $\mathrm{F}$. The case presented here evidently shows the costs of the "tragedy of the commons".

The assumptions and technical choices made in the construction and analysis of the bioeconomic model are supported and reasoned by existing literature, but also by the interviewed fishermen. For instance, the simulation results suggest that lowering the fishing mortality level in an age-structured model increase the fish size. Also, the fishermen pointed out the possibility for the increasing amount of larger food herring in catches. We assumed that the trading of quotas is allowed among fodder trawlers and among food trawlers; not between the segments. Also, the fodder herring fishermen saw that entry into food herring market is very difficult.

An obstacle to fishery policy change might be short-term planning, since within ITQs the greater catches materialize after 15 years (see fig. 2). But, for instance, demand increase may enable greater catches within shorter time. After all, the long term catch level that maximize the net present value of the BS herring fishery within an ITQ-system, is half of the latest catches (46 $000 \mathrm{t}$ in 2002 and 2003, ICES 2004). Naturally, this result is highly dependent on 
the parameters of the S/R model applied. If the S/R parameters estimated by ICES are correct, the biologically safe fishing mortality level actually leads to recruitment overfishing (when S/R model is applied, the total catch would be higher with lower F). Consequently, there exists a conflict between the reference points of $\mathrm{F}$ and S/R parameters.

The present study provides guidelines for economic and biological sound management of the Finnish herring fishery. Due to the data limitations, the absolute numerical results should be treated with appropriate reservation. However, we believe that our conclusions are not sensitive on uncertainties in the data. Obviously, the economic performance of the fishery could be improved from the present situation while maintaining larger herring stock compared to the current policy. It is important to note, that the economic advice for the optimal fishing mortality level is $60 \%$ smaller than the current recommendations, thus economic advice that considers both the fishing costs and discount rate would lead to a greater stock size than the current biological criteria.

We find that the current management of the BS herring fishery is far from being economically as well as biologically sound and an ITQ-system would be a good alternative for current management system. The results of interviews support the results of bioeconomic analysis and envisage good opportunities for the implementation of ITQ-system to the Finnish herring fishery. This present study supports a conclusion that co-management could be preferred. The multidisciplinary study presented here, captures the fundamental topics of fisheries management and provides relevant guidelines for fisheries managers for successful implementation of the new herring fishery policy.

\section{Acknowledgements}

Financial support from Finnish Ministry of Agriculture and Forestry is acknowledged. We acknowledge interviewed fishermen, the officers of Ministry of Agriculture and Forestry and researchers from Finnish Game and Fisheries Research institute for cooperation. An earlier version of this paper was presented to Workshop on: New Developments in Rights-based Fisheries Management: Community Fishing Rights, Esbjerg, 29-30 August 2005, encouraging atmosphere of the workshop and the comments of the other participants are acknowledged. Valuable comments from Nina Hyytiä, Anna-Kaisa Kosenius and Amy Burnett are gratefully acknowledged. 


\section{References}

Anon., 2003. Economic Assessment of European Fisheries. Economic Performance of Selected European Fishing Fleets. Annual Report 2003.

FGFRI (Finnish Game and Fisheries Research Institute), 2001a. Finnish Fishery Time Series. SVT 2001:60.

FGFRI (Finnish Game and Fisheries Research Institute), 2001b. Produces Prices for Fish 2001. Finnish Game and Fisheries Research Institute. Agriculture, Forestry and Fishery, 51.

FGFRI (Finnish Game and Fisheries Research Institute), 2001c. Produces Prices for Fish 2000. Finnish Game and Fisheries Research Institute. Agriculture, Forestry and Fishery, 45.

FGFRI (Finnish Game and Fisheries Research Institute), 2003. Produces Prices for Fish 2002. Finnish Game and Fisheries Research Institute. Agriculture, Forestry and Fishery, 54.

FGFRI (Finnish Game and Fisheries Research Institute), 2005. Commercial Marine Fishery 2004. SVT. Maa-, metsä-, ja kalatalous 2005:57.

Adasiak, A., 1979. Alaska's experience with limited entry. Journal of the Fisheries Research Board of Canada 36(7), 770-782.

Arnason, R., 1990. Minimum information management in Fisheries. Canadian Journal of Economics (23)3, 630-653.

Arnason, R., 1993. Icelandic fisheries management. In: The use of individual quotas in fisheries management. OECED documents, 123-144.

Arnason, R., Gissurarson, H.H., (Eds.) 1999. Individual transferable quotas in theory and practise. Papers exploring and assessing the radical reorganization of ocean fisheries in the final decades of the $20^{\text {th }}$ century. The University of Iceland Press. Reykjavik

Batsone, C.J., Sharp, B.M., 2003. Minimum information management systems and ITQ fisheries management. Journal of Environmental Economics and Management 45, 492-504.

Campbell, D., Brown, D., Battaglene, T., 2000. Individual transferable catch quotas: Australian experience in the Southern bluefin tuna fishery. Marine Policy 24, 109-117.

Clark, C.W., 1980. Towards a predicative model for the economic regulation of commercial fisheries. Canadian Journal of Fisheries and Aquatic Sciences 37, 1111-1129.

Clark, C.W., 1990. Mathematical bioeconomics: the optimal management of renewable resources. New York. Wiley.

Couper, A.D., Smith, H.D., 1997. The development of fishermen-based policies. Marine Policy 21(2), 111-119.

Fraser, G.A., 1979. Limited entry: experience of the British Columbia salmon fishery. Journal of the Fisheries Research Board of Canada 36(7), 754-763. 
Gordon, S.H., 1954. The economic theory of a common property resource: The fishery. Journal of Political Economy 62, 124-142

Grafton, R.Q., 1996. Experiences with individual transferable quotas: An overview. The Canadian Journal of Economics (29), Special Issue: Part, 135-138.

Gridle, K.R., Macinko, S., 2000. A requiem for the IFQ is US fisheries? Marine Policy 24(6), 461-469.

Hannesson, R., 1991. From common fish to rights based fishing. Fisheries management and the evolution of exclusive rights to fish. European Economic Review 35, 397-407.

ICES, 2003. Report of the Baltic Fisheries Assessment Working Group. ICES Headquarters April 2003.

ICES, 2004. Report of the ICES Advisory Committee on Fishery Management and Advisory Committee on Ecosystems, 2004. ICES Advice 1(2), 2-744 - 2-755.

Jentoft, S., 1989. Fisheries co-management. Delegating government's responsibilities to fishermen's organisations. Marine Policy, 13(2), 137-54.

Kulmala, S., 2005. Individual transferable quotas in the Bothnian Sea herring fishery: a bioeconomic analysis. University of Helsinki, Department of Economics and Management, Working paper n:o 29. (in Finnish) http://www.honeybee.helsinki.fi/mmtal/abs/Selv29.pdf

McCay, B.J., 1995. Social and ecological implications of ITQs: an overview. Ocean \& Coastal Management (28)1-3, 3-22.

Maurstad, A., 2001. Fishing in murky waters - ethics and policies of research of fisher knowledge. Marine Policy 26,159-166.

Mickwitz, P., Pruuki, V., 1993. Individual Transferable Quotas in the Finnish Salmon Fishery. Prospects for the Future. In: The Use of Individual Transferable Quotas in Fisheries Management. OECED documents, 15-33.

Moloney, D.G., Pearse, P.H., 1979. Quantitative rights as an instrument for regulating commercial fisheries. Journal of the Fisheries Research Board of Canada 36(7), 859-866.

Peltomäki, H., 2004. Yksikkökohtaiset kalastuskiintiöt kalastusksensäätelyssä: Silakan troolikalastajan näkökulma ja säätelyn vaikutus Selkämeren silakkakantaan. Master's Thesis, University of Helsinki, Faculty of Bio- and Environmental Sciences. 120 p.

http://ethesis.helsinki.fi/julkaisut/bio/bioja/pg/peltomaki/

Scott, A., 1999. Fishermen's property rights. In: Arnason, R., Gissurarson, H., (Eds.) 1999. Individual transferable quotas in theory and practice. Papers exploring and assessing the radical reorganization of ocean fisheries in the final decades of the $20^{\text {th }}$ century. The University of Iceland Press. Reykjavik 
Squires, D., Campbell, H., Cunningham, S., Dewees, C., Grafton, R.Q., Herrick, S.F,, Kirkley, J., Pascoe, S., Salvanes, K., Shallard, B., Turris, B., Vestergaard, N., 1998. Marine Policy 22(2), 135-159.

Stephenson, R., Peltonen, H., Kuikka, S., Pönni, J., Rahikainen, M., Aro, E., Setälä,J. 2001. Linking biological and industrial aspects of the Finnish commercial herring fishery in the Northern Baltic Sea. pp 741 - 760. In: Funk, F., Blackburn, D., Hay, D., Paul, A. J., Stephenson, R., Toresen, R., and Witherel, D. (eds). Herring: expectations for a new millennium. University of Alaska Sea Grant, AK-SG-01-04, Fairbanks. 800 pp.

Terry, J.M., 1993. Individual transferable quotas for the fixed gear sablefish and halibut fisheries of Alaska. In: The use of individual quotas in fisheries management. OECED documents, 95-121.

Townsend, R.E., 1992. Bankable individual transferable Quotas. Marine Policy, 16(5), 345348.

Vetemaa, M., Eero, M., Hannesson, R., 2002. The Estonian fisheries: from the Soviet system to ITQs and quota auctions. Marine Policy 26, 95-102. 
Discussion Papers:

No.

1. Jussi Lankoski, Markku Ollikainen \& Pekka Uusitalo (2004): No-till technology: benefits to farmers and the environment?" Environmental Economics.

2. Stefan Bäckman \& Alfons Oude Lansink (2004): Crop and soil specific mineral efficiency and productivity in Finland. Production Economics and Farm Management.

3. Antti Iho (2004): Cost-effective reduction of phosphorus runoff from agriculture: a numerical analysis. Environmental Economics.

4. Jussi Lankoski, Erik Lichtenberg \& Markku Ollikainen (2004): Performance of alternative policies in addressing environmental dimensions of multifunctionality. Environmental Economics.

5. Kyösti Arovuori \& Jukka Kola (2004): Experts' opinions on policies and measures for multifunctional agriculture. Agricultural Policy.

6. Erikki Koskela, Markku Ollikainen \& Timo Pukkala (2004): Biodiversity policies in commercial boreal forests: optimal design of subsidy and tax combinations. Environmental Economics.

7. Lone Grønbæk Kronbak \& Marko Lindroos (2005): Sharing rules and stability in coalition games with externalities: the case of the Baltic Sea cod fishery. Environmental Economics.

8. Nina Hyytiä \& Jukka Kola (2005): Citizens' attitudes towards multifunctional agriculture. Agricultural Policy.

9. H. Dahlbo, M. Ollikainen, S. Peltola, T. Myllymaa \& M. Melanen (2005). Combining ecological and economic assessment of waste management options - case newspaper. Environmental Economics.

10. Aleksandar Shivarov, Soile Kulmala \& Marko Lindroos (2005). Fisheries Management Costs: The Case of Baltic Salmon Fishery. Environmental Economics. 